УДК 504.06

DOI: $10.17586 / 2310-1172-2021-14-3-117-128$

Scientific article

\title{
Awareness of Sustainable Use of National Natural Resources as a Basis for the Environmental Protection Systems: Economic Aspects and the New Global Index of the Popularity of Environmental Queries (GIPEQ)
}

\author{
Ph.D. Shemetev A.A. shemetev-aa@ranepa.ru \\ FPBI HVE Russian Academy of National Economy and Public Administration at the President \\ of the Russian Federation, North-Western Institute of Management \\ 199178, Russia, Saint-Petersburg, Sredny prospect of Vasylievsky isle, 57
}

The most popular in science "Environmental Performance Index" (EPI) is too narrowly specific. EPI might only be popular in a limited number of countries, this research reveals. This index is designed to assess the sustainable use of natural resources and the effectiveness of environmental protection systems. This index has collected the most advanced scientific researches with an impact factor in this area. However, its actual application might be limited among narrow specialists in 11 countries, this research reveals. This study proposes a new index. This is a global index of the popularity of environmental queries (GIPEQ). It shows the cumulative global popularity of environmental queries for the world as a whole and for each country separately (from the search engines like Google). It might also be applied as an EPI index deflator for the time series analysis. The algorithm for creating the GIPEQ index is written in the R programming language for this study. Data privacy is ensured by using a percentage of the absolute maximum value. This approach allows working with confidential data. This study is divided into 3 parts. Part 1 discusses why the EPI is the most advanced study for assessing the sustainable use of natural resources and the effectiveness of environmental protection systems for every country in the world. The second part discusses the shortcomings of the EPI index. They include the impossibility of analyzing time series (the method for assessing the index changes significantly every year) and a significant amount of missing data in the most basic components of the index. This is shown by using the example of assessing the quality of water and fish resources (out of almost one and a half thousand components of the EPI index). The third drawback is the popularity of this index among the public, this research suggests. A new index (GIPEQ) is proposed and the necessity of its application is justified in the third part of this research. Widespread public demand for environmental programs creates pressure for politicians. This pressure should stimulate them to develop a system of sustainable use of natural resources and environmental protection. The research question: what indicator could estimate the popularity of ecology and environmental programs in the world? The additional research question is how to estimate it? The main hypothesis is that this indicator could potentially be used for estimating the time series of the complex EPI by estimating the EPI deflator. Deflating the EPI from a specific period is the only known way to control for the timeseries analysis for the EPI indicator, this research suggests. The main assumption is that this indicator could potentially be used for estimating the pressure of the public opinion to policymakers for stimulating the development of ecological programs that will be seen through the better environmental performance criteria.

Keywords: sustainable use of natural resources; environmental protection systems; Global Index of the Popularity of Environmental Queries, GIPEQ.

Осведомленность об устойчивом использовании национальных природных

ресурсов как основа для систем защиты окружающей среды: экономические аспекты и новый глобальный индекс популярности экологических запросов (GIPEQ)

\author{
Канд. экон. наук Шеметев А.А. shemetev-aa@ranepa.ru \\ ФГБОУ ВПО Российская Академия Народного Хозяйства и Государственной Службы \\ при Президенте РФ, Северо-Западный Институт Управления \\ 199178, Россия, Санкт-Петербург, Средний проспект В.О. 57
}




\section{Научная статья}

Самый популярный в науке "Индекс экологической результативности» (ЕРІ) носит слишком узкий характер. Исследование показывает, что ЕРІ может быть популярен только в ограниченном числе стран. ЕРІ индекс предназначен для оценки устойчивого использования природных ресурсов и эффективности систем зациты окружающей среды. В этом индексе собраны самые передовые научные исследования с импакт-фактором в этой области. Однако настоящее исследование показывает, что его практическое применение может быть ограничено узкими специалистами в 11 странах. В этом исследовании предлагается новый индекс. Это глобальный индекс популярности экологических запросов (GIPEQ). Он показывает совокупную глобальную популярность экологических запросов для мира в целом и для каждой страны в отдельности (от поисковых систем, таких как Google). Еzо также можно использовать в качестве дефлятора индекса ЕРI для анализа временных рядов. Для данного исследования алгоритм создания индекса GIPEQ написан на языке программирования $R$. Конфиденциальность данных обеспечивается за счет использования процента от абсолютного максимального значения. Такой подход позволяет работать с конфиденциальными данными. Это исследование разделено на 3 части. В Части 1 обсуждается, почему ЕРІ является наиболее передовым исследованием для оценки устойчивого использования природных ресурсов и эффективности систем зациты окружающей среды для каждой страны мира. Во второй части обсуждаются недостатки индекса ЕРІ. К ним относятся: невозможность анализа временных рядов (метод оценки индекса существенно меняется каждый год) и значительный объем отсутствующих данных в самых основных компонентах индекса. Это показано на примере оценки качества водных и рыбных ресурсов (из почти полутора тысяч компонентов индекса ЕРІ). Третий недостаток - популярность этого индекса среди населения, как установлено в данном исследовании. В третьей части исследования предлагается новый индекс (GIPЕQ) и обосновывается необходимость его применения. Широкий общественный спрос на экологические программы оказывает давление на политиков. Это давление должно стимулировать их к развитию системы устойчивого использования природных ресурсов и защиты окружающцей среды. Вопрос исследования: по какому показателю можно оценить популярность экологии и экологических программ в мире? Дополнительньй вопрос исследования: как это оценить? Основная гипотеза состоит в том, что этот индикатор потенциально может быть использован для оценки временных рядов сложного ЕРІ путем оценки дефлятора ЕРІ. Данное исследование предполагает, что дефляция ЕРІ за определенный период - единственный известный способ контролировать анализ временных рядов индикатора ЕРІ. Основное предположение состоит в том, что этот индикатор потенциально может быть использован для оценки давления общественного мнения на политиков с целью стимулирования разработки экологических программ, которые будут рассматриваться с помощью более эффективных критериев экологической результативности. Ключевые слова: рациональное использование природных ресурсов; системы защиты окружающей среды; Глобальный индекс популярности экологических запросов, GIPEQ.

\section{Introduction}

The most popular in science "Environmental Performance Index" (EPI) is too narrowly specific. EPI might only be popular in a limited number of countries, this research reveals. This index is designed to assess the sustainable use of natural resources and the effectiveness of environmental protection systems. This index has collected the most advanced scientific researches with an impact factor in this area. However, its actual application might be limited among narrow specialists in 11 countries, this research reveals.

This study proposes a new index. This is a global index of the popularity of environmental queries (GIPEQ). It shows the cumulative global popularity of environmental queries for the world as a whole and for each country separately (from the search engines like Google). It might also be applied as an EPI index deflator for the time series analysis. The algorithm for creating the GIPEQ index is written in the $\mathrm{R}$ programming language for this study. Data privacy is ensured by using a percentage of the absolute maximum value. This approach allows working with confidential data.

This study is divided into 3 parts. Part 1 discusses why the EPI is the most advanced study for assessing the sustainable use of natural resources and the effectiveness of environmental protection systems for every country in the world. The second part discusses the shortcomings of the EPI index. They include the impossibility of analyzing time series (the method for assessing the index changes significantly every year) and a significant amount of missing data in the most basic components of the index. This is shown by using the example of assessing the quality of water and fish resources (out of almost one and a half thousand components of the EPI index). The third drawback is the popularity of this index among the public, this research suggests. 
A new index (GIPEQ) is proposed and the necessity of its application is justified in the third part of this research. Widespread public demand for environmental programs creates pressure for politicians. This pressure should stimulate them to develop a system of sustainable use of natural resources and environmental protection.

The research question: what indicator could estimate the popularity of ecology and environmental programs in the world? The additional research question is how to estimate it? The main hypothesis is that this indicator could potentially be used for estimating the time series of the complex EPI by estimating the EPI deflator. Deflating the EPI from a specific period is the only known way to control for the time-series analysis for the EPI indicator, this research suggests.

The main assumption is that this indicator could potentially be used for estimating the pressure of the public opinion to policymakers for stimulating the development of ecological programs that will be seen through the better environmental performance criteria.

\section{Review of sources}

The first works devoted to the analysis based on the macroeconomic data dates back to 1941 (S. Kuznets, 1941; S. S. Kuznets, 1941; Smith, 1942). Any basic decisions related to the macroeconomic are based on the macroeconomic data analysis since that time. At the same time, such analysis does not involve any environmental indicators connected with the environmental protection systems or sustainable use of national natural resources.

The classical approach for the analysis of the development of regions and nations omits the environmental basis and depletion of natural resources. In particular, the most important indicators of regional and national development are related to the GDP GRP or GNI PC; these indicators do not pay significant attention to the environmental factors. Some firms could decrease their costs by saving on environmental technologies and methods. Thus, they transfer these costs to the local, regional, and national governments and society as a whole. Some countries cannot afford to deal with those externalities properly. The accent on economic growth and regional development (in terms of the indicators) could leave the environmental problems without proper attention. Fish stocks, biodiversity, forests, oil, gas resources, ores, - they should also be taken into account. This could create a bias where countries look richer than they are in reality (Atkinson et al., 1997). Some rich countries could actually have almost no resources. Some poorer countries could avoid spending on removing externalities. The true indicator of national and regional development should be capable to consider the growth of income considering the endless number of future periods. This should grant generating the same or even greater amounts of income in the infinite number of future periods (Hicks, 1959). The core of this problem is sustainable capital utilization.

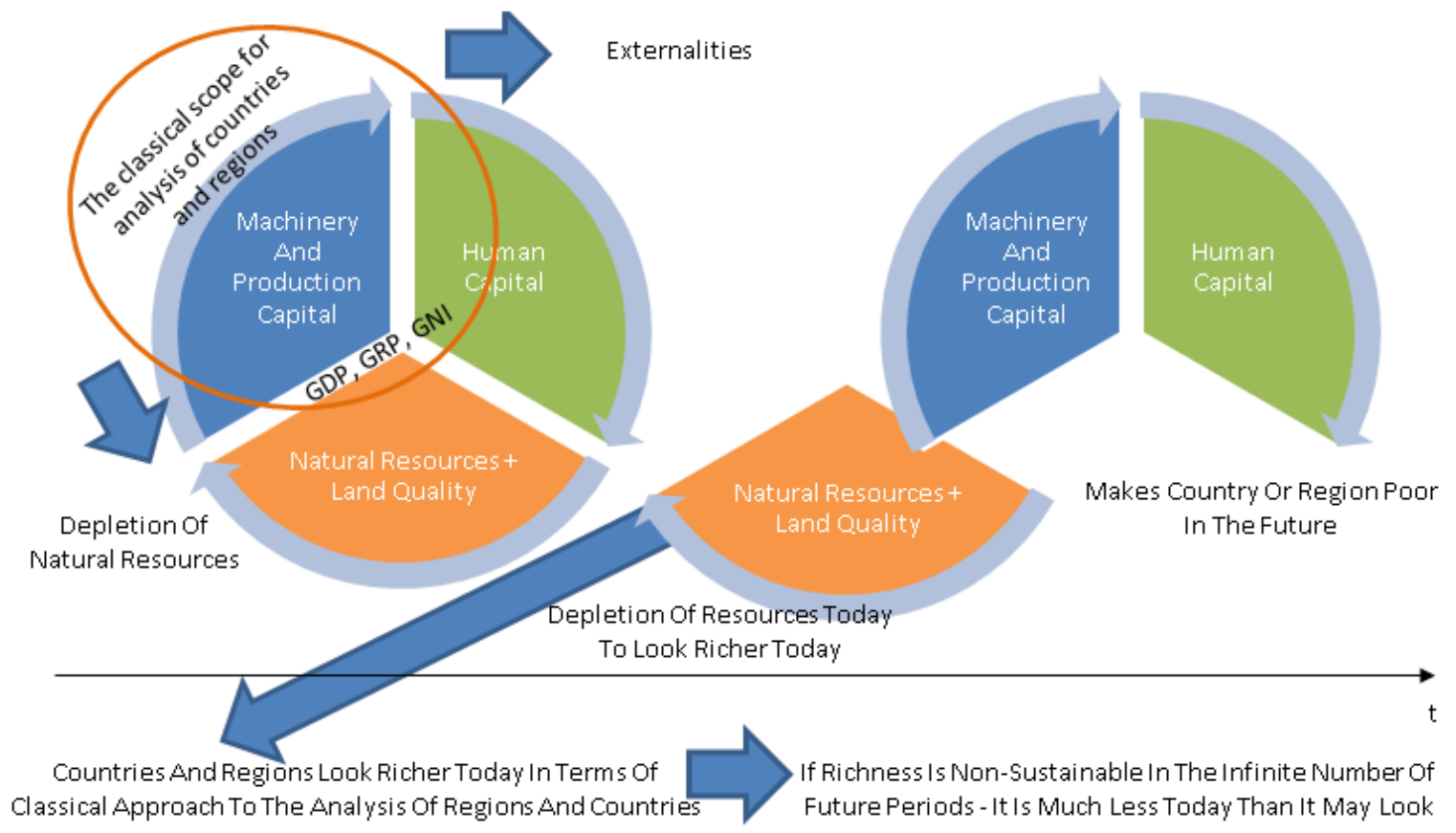

\section{Fig. 1. Correlation of the GDP/GRP/GNI (PC) and social welfare in the national and regional economies within the environmental economic theory framework ${ }^{l}$}

This concept is a continuation of the lexicographic theory. GDP/GRP/GNI measure progress by the market commodities (like blocks of flats, cars, water supply system, holidays at exotic places, highways). Nevertheless, in reality, this could be not the measures of progress but the substitutes of the real variable. The real variable could be something

${ }^{1}$ Source: own elaboration to show the place of the GDP/GRP/GNI. 
related to space, comfort, direct access to nature, pure water. The commodities that the market offers are only substitutes for the actual needs of people. People do not need the endless quantities of the commodities that the market could potentially offer to increase the GDP/GRP/GNI per capita to the maximum value. People only need to fulfill their real needs ${ }^{2}$. Improving and increasing the quantity and quality of commodities at the market can only increase social welfare partially up to some threshold (Helliwell, 2003), as mentioned in the lexicographic theory part (Max-Neef, 1995). In addition to this, the extra production of commodities that increases GDP and similar indicators can lead to the depletion of natural resources and environmental externalities (Day, 1971; Encarnacion, 1964; Georgescu-Roegen, 1954; Tversky, 1972). Any progress should be regarded from the perspective of sustainability in an infinite number of future periods (Gerlagh, Dellink, Hofkes, \& Verbruggen, 2002; Hofkes, Gerlagh, \& Linderhof, 2011; López \& Mitra, 2000). Thus, some regions that just quickly exploit their natural resources and produce more nowadays might just look richer than they are in reality (Weitzman \& Löfgren, 1997). In opposite to this, some regions that may look poorer nowadays might be richer ${ }^{3}$ in reality due to the fact that they preserved their sustainable environment and quality of the land for long prospects (Brekke, Howarth, \& Nyborg, 2003; Daniel \& Ehrlich, 1990; Gilland, Daly, \& Cobb, 1990).

One of the most comprehensive studies on environmental analysis in economics is the Yale University EPI Index (Yale University, 2021). This index is in the process of formation and improvement now. This means that every year the methodology for accounting for the main components of this index changes significantly (Conrad \& Cassar, 2019; Wendling, Emerson, de Sherbinin, \& Esty, 2020). Thus, this index is not suitable for time series analysis. It is suitable for analyzing the state of ecology of different countries in comparison in each specific period. At the same time, there is no way to trace the dynamics of changes. The annual change in the methodology makes the data not comparable.

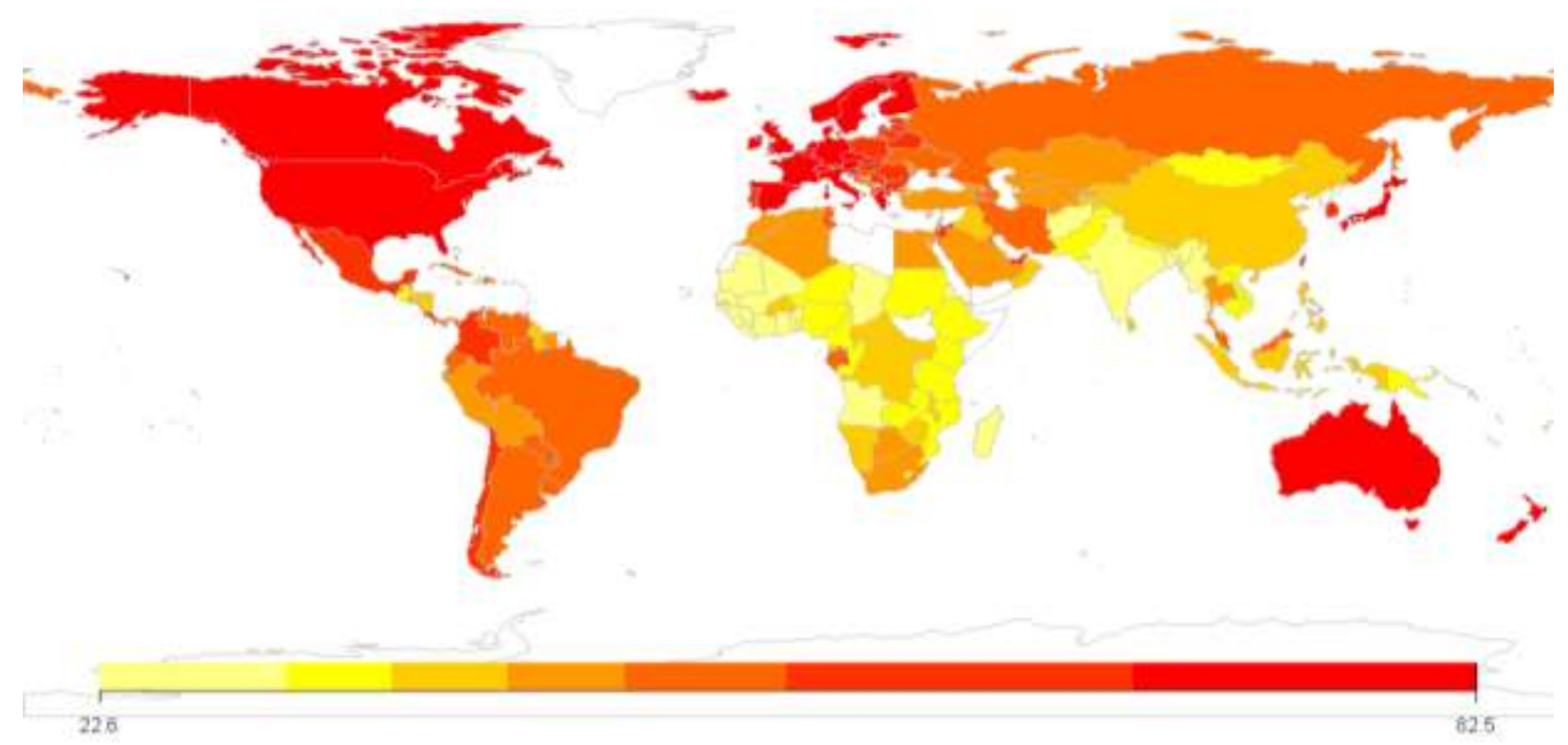

Fig. 2. Cumulative Environmental Performance Index of the countries of the world (0 - minimum, 100 - maximum), $2019^{4}$

It can be seen that Russia is in the middle, in terms of environmental standards in 2019. Countries with the highest level of development of ecological technologies and environmental preservation are highlighted in red. Orange color is used for countries that are doing average with the above indicators. Countries that have colossal systemic problems (from an environmental point of view) are marked in yellow. Countries for which we could not find data are highlighted in white. Thus, it can be seen that the countries that can maintain the ecology at a sufficiently high level are relatively small in terms of the total area of the territory on the globe. In addition, countries that cannot maintain their ecology occupy a large territory of the globe in terms of their total area. Therefore, even the successes of small and some large states in ecology cannot be

\footnotetext{
${ }^{2}$ For example, some researchers (Fonte, 2013) suggest that people might even gather in groups to pucrhase commodities directly from producers for environmental and utility issues to fulfill their real needs.

${ }^{3}$ This research speaks about the regions, not individuals, because it might be true that physical environmental factors can be insignificantly correlated with the life expectancy [a proxy for the quality of life] (Chetty et al., 2016). At the same time, this concept might be arguable, because environmental quality can be an important factor of the quality of life (Arrow et al., 2004; Batabyal \& Dasgupta, 2002; Dasgupta \& Mäler, 2000).

${ }^{4}$ Compiled by the author in the programming language R. Data - Yale University (Yale University, 2021).
} 
considered absolute, insofar as most of the territory of the globe is governed by standards that contradict the basic ecological principles.

The Extended Environmental Index $\left(\mathrm{EPI}^{5}\right)$ database includes 241 countries and 1417 indicators. These indicators are reduced to a single indicator (ecological index, EPI) which is shown in Figure 2. Nevertheless, the components of the ecological index are (most often) not comparable from the perspective of the time series analysis. As an example, two components of the ecological index are given below: the availability of water resources and the availability of fish resources.

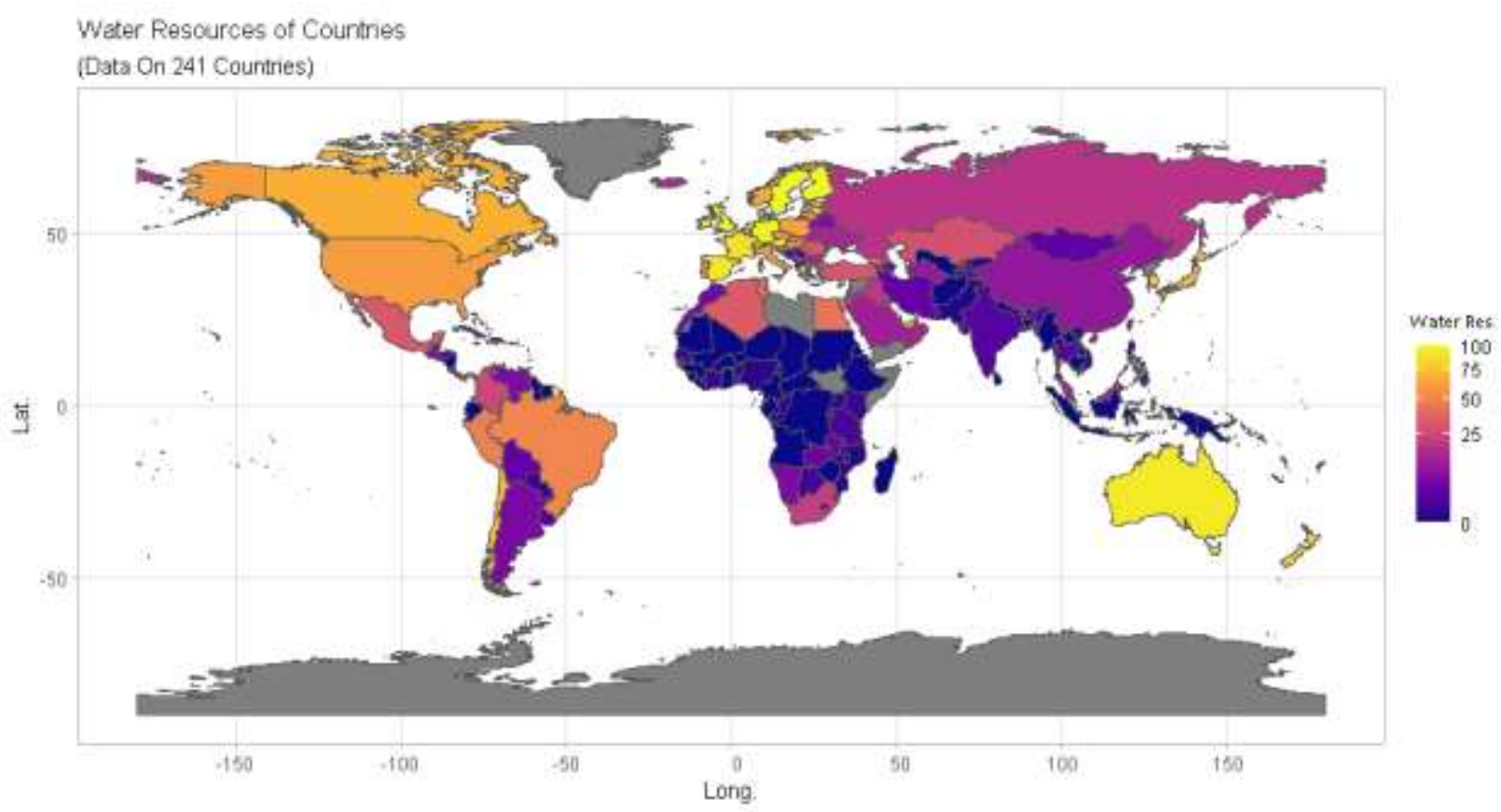

Fig. 3. \% of the availability of water resources of the countries of the world (0 - minimum, 100 - maximum), $2019^{6}$

Despite the high standards of water purification, the Russian Federation has a low rating in terms of water availability and purity. The infrastructure in the Russian Federation is of rather low quality, and tap water cannot be drunk without boiling. There are many chemical elements and pollutants in water. Enterprises can discharge their waste into water bodies. Thus, the availability of water resources in the Russian Federation is below average.

The quality of ecology is connected with water. One of the interrelated variables is the indicator of fish resources. Fish is an important nutrient and an important indicator of the state of the ecology of water bodies. The volume of fish resources decreases with a large discharge of waste into water bodies. In addition, some countries might lack a large number of natural reservoirs. The data are shown in Figure 4.

\footnotetext{
${ }^{5}$ Better known as Cumulative Environmental Performance Index, or EPI.

${ }^{6}$ Compiled by the author in the programming language R. Data - Yale University (Yale University, 2021). The environmental researches are interrelated. For example, quality of the basic resources (like water) can influence the overall economic development (Gibbs, 2005) and eco-tourism (Gabe, 2017).
} 


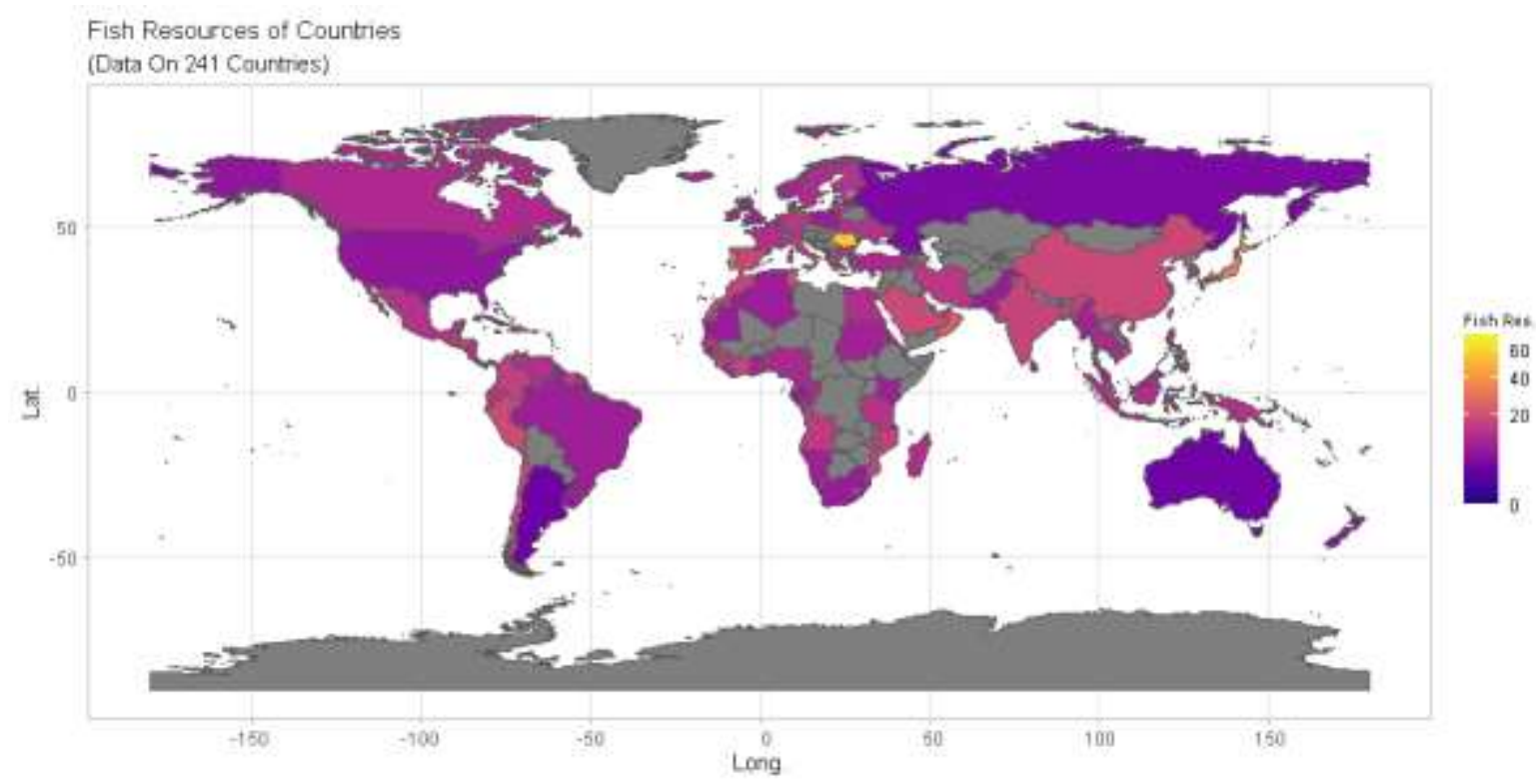

Fig. 4. \% of the availability of fish resources of the countries of the world (0 - minimum, $100-$ maximum), $2019^{7}$

Fish is not found only in the department stores, water is not only in distilled bottles, - everything is interconnected in the general ecosystem of the globe. Population growth only exacerbates the problem of ensuring sustainable use of national natural resources (Hayek \& Bartley, III, 2013). Unfortunately, the countries with the most populations are not yet able to cope with the environmental and other problems of their environmental protection systems on their own. They need the help of the entire world community. Only under such conditions can we achieve sustainable use of national natural resources in each country, while it is important to understand that it is impossible to achieve high environmental standards in a single country alone.

\section{Problems and Methodology}

As discussed in the previous section, the expanded environmental index (EPI) consists of 241 countries and 1417 indicators, from which the aggregate EPI index is derived. At the same time, much data is missing. This is shown in figure five for the variables discussed in this paper. The indices of water and fish resources are taken. These indices are important components of the EPI calculation.

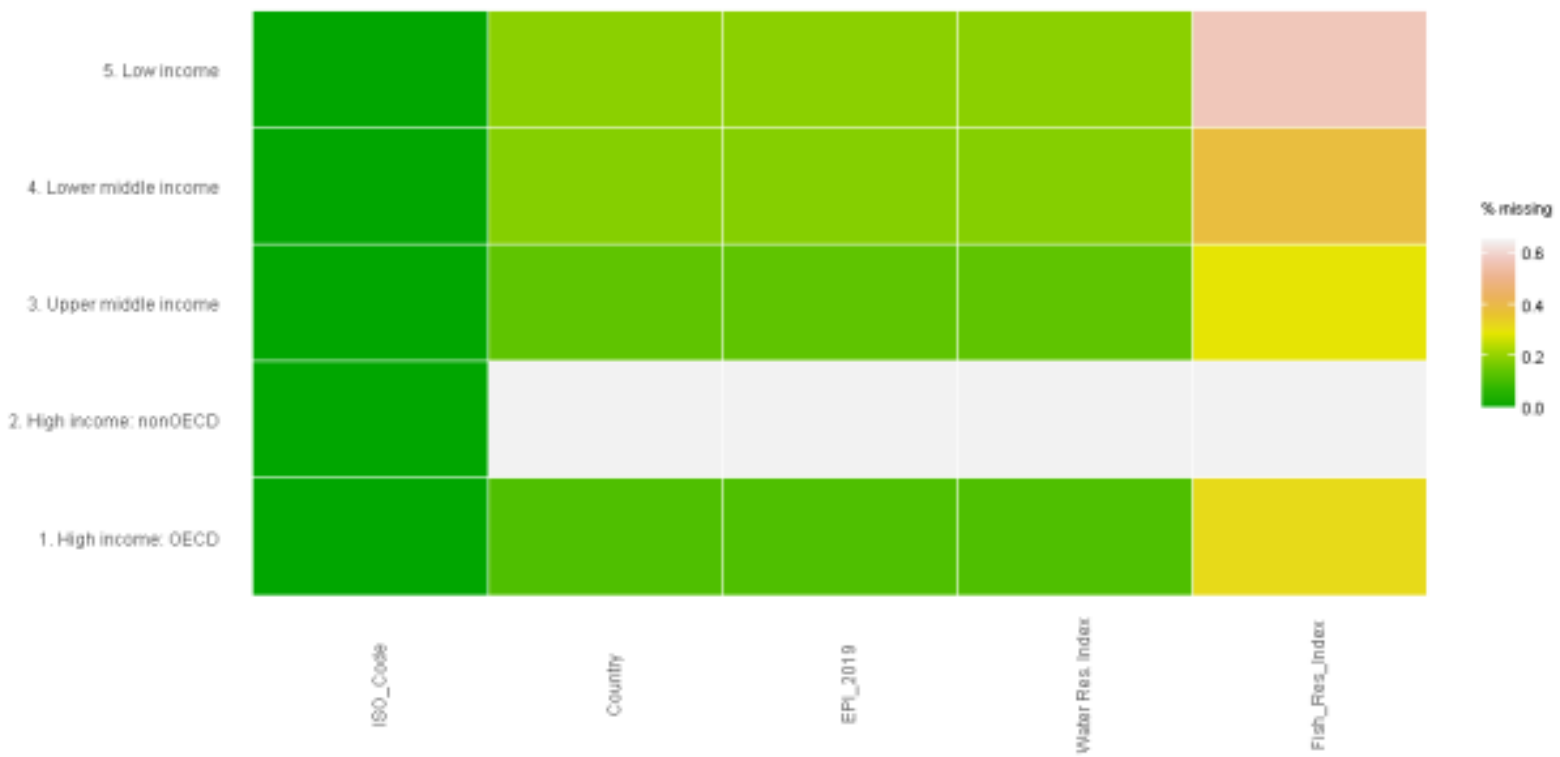

Fig. 5. \% of missing data in some components of the EPI index, 2019

\footnotetext{
${ }^{7}$ Compiled by the author in the programming language R. Data - Yale University (Yale University, 2021).
} 
The author has created special code in the $\mathrm{R}$ programming language that displays missing data in databases, for example, in EPI. The R package is named "alexandershemetev" (Shemetev, 2020). The "alex_na_plot" function creates a graph as in fig. $5^{8}$, which is displayed in green for years and indicators for which most of the available data is available. Indicators for which approximately half of the data is available are shown in yellow. Indicators for which about $25 \%$ of the data are available are shown in red. Gray is typical for data for which we have 0 to $10 \%$ of the data available.

Missing data might be the reason for incorrect EPI calculations. The Environmental Performance Index (EPI) is the main index itself. The "Water Res. Index" is one of the constituent components of the EPI index. The availability of fish resources (Fish_res_Index) is related to the state of water resources (fish lives in water). That is, the deeper the researcher delves into the data (on the basis of which the final EPI is compiled), the fewer data will be available for assessment. This can serve as a rather serious barrier to the wider application of the named index.

Another important feature of the EPI index is the incomparability of time series. The change in methodology every year makes it impossible to conduct a qualitative analysis of time series. As a result, the researcher cannot say whether the situation in a particular country is improving or deteriorating related to environmental indicators. If, for example, the goal is to assess the sustainable use of natural resources, then, this can only be done for one time period, based on the largest environmental study for the economy. At the same time, it is impossible to say qualitatively whether the situation is improving or worsening in the country over time (according to this criterion). As a result, it is impossible to say how much the system of environmental protection in the country is changing. Consequently, it is impossible to talk about the economic efficiency of these two systems over time.

Other researches (in the field of sustainable use of natural resources and environmental protection systems) are significantly less complex than the EPI. As a rule, they are devoted to some parts of these systems. EPI tried to combine various impact-studies into a single indicator. But the drawback of all studies is either the impossibility of using this data for time series analysis, or the estimation is too narrow.

This study suggests a different method. This method uses unloading from search engines. The most popular global search engine today is Google. More and more users are switching to mobile devices. The operating system from Google is one of the most popular. This system has in-built search programs from Google. Google also has versions of browsers for personal computers and other devices. This study suggests that Google is the most important global provider of trend data. Thus, the researcher is able to obtain proxy variables and latent variables for further analysis of the sustainable use of natural resources and environmental protection systems.

An algorithm for extracting global data for various categories of search queries has been prepared (as a part of this study). The algorithm transforms the data into a matrix that includes the countries and interests at the given dates (usually: from January 1, 2004, to the present).

Particular attention is paid to data privacy when using Google search queries. The researcher would like to get the data down to each specific request in as much detail as possible. At the same time, such data will be minimally confidential. The proposed algorithm uses the percentage of the maximum for all periods for all countries to obtain completely confidential data. This approach makes the data completely confidential. Thus, the algorithm initially operates only with confidential data of the percentage ratio of the absolute maximum for each country and for each period. The absolute maximum is one for each output from the search engine.

In addition, several modifications of the code are made in the $\mathrm{R}$ programming language, which allows performing other operations with this data. For example, these codes allow the creation of different charts of the interests of the population of different countries at different time periods, regarding requests for sustainable use of natural resources and environmental protection systems. Any researcher can get a proxy for time series analysis based on this output.

Thus, the study provides a tool for obtaining data on the development of interest in the sustainable use of natural resources and environmental protection systems. The higher the public interest in these topics, the more demand the public creates for policymakers. The increased demand creates additional incentives for political decisions in favor of improving environmental protection systems. That is, high public demand for environmental problems compels politicians to improve systems for environmental protection and sustainable use of natural resources. A weakening of public demand for this improvement can reduce the pressure on politicians and, thus, stop positive changes in these systems.

\section{The Main Results and Discussion}

The methodology part explains why the EPI cannot be used for time series analysis (annual methodology changes). Moreover, the missing data for calculating the components of this index is also a barrier.

This study proposes a new approach. It uses unloading from search engines (mainly from Google). These unloadings allow seeing changes in public interest in environmental issues at different levels. This study suggests that trends in public inquiry can be used as latent and proxy variables in the analysis.

\footnotetext{
${ }^{8}$ The ,ts_id" parameter (as factor) is set to the income groups.
} 
To ensure data confidentiality, the absolute maximum for the entire search history is used for each individual country. It is impossible to obtain the confidential data of individual users with this approach. At the same time, the overall indicator remains stable and accurately reflects all trends.

The most popular environmental indicator is the Environmental Performance Index (EPI). The peak of its popularity fell on the moments of its creation. This indicator has no stable popularity. Moreover, during certain periods of history, interest in this indicator dropped to 0 requests worldwide per month. That is, the general public might not often use professional indicators to assess the sustainable use of natural resources and environmental protection systems. The use of various abbreviations of the index name is also taken into account in the analysis.

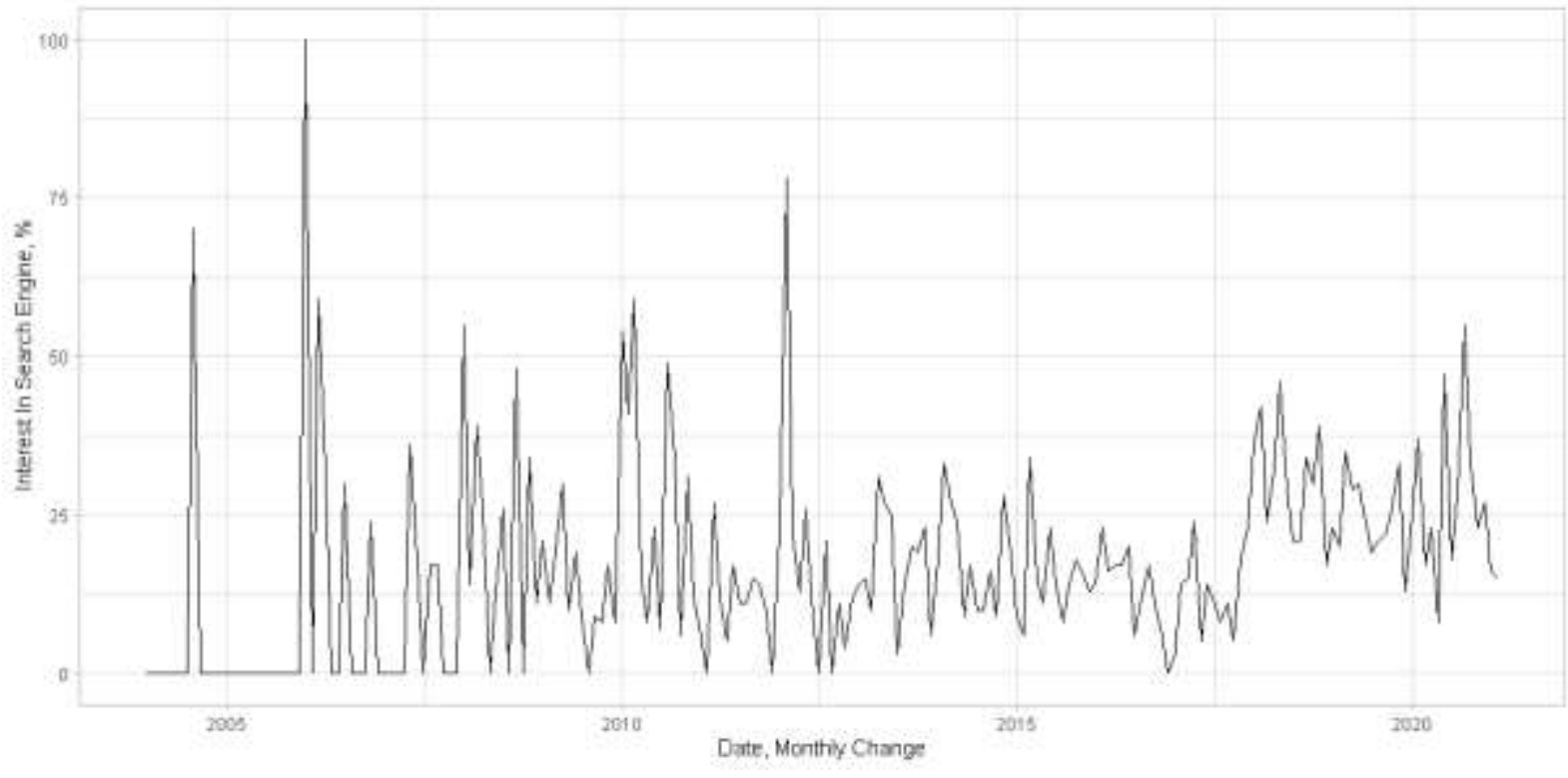

Fig. 6. The global requests on the Environmental Performance Index (EPI), \% of the maximum historical value (Jan-2004 - Feb-2021)

Figure 6 is made in this research in the programming language called $\mathrm{R}$ by obtaining the S3-type data ${ }^{9}$ from Google search and transforming it to a common data frame (type of R-specific data formats). The seasonality of the search pattern data is verified by a special $\mathrm{R}$ algorithm designed for this research ${ }^{10}$ (figure 7 ).

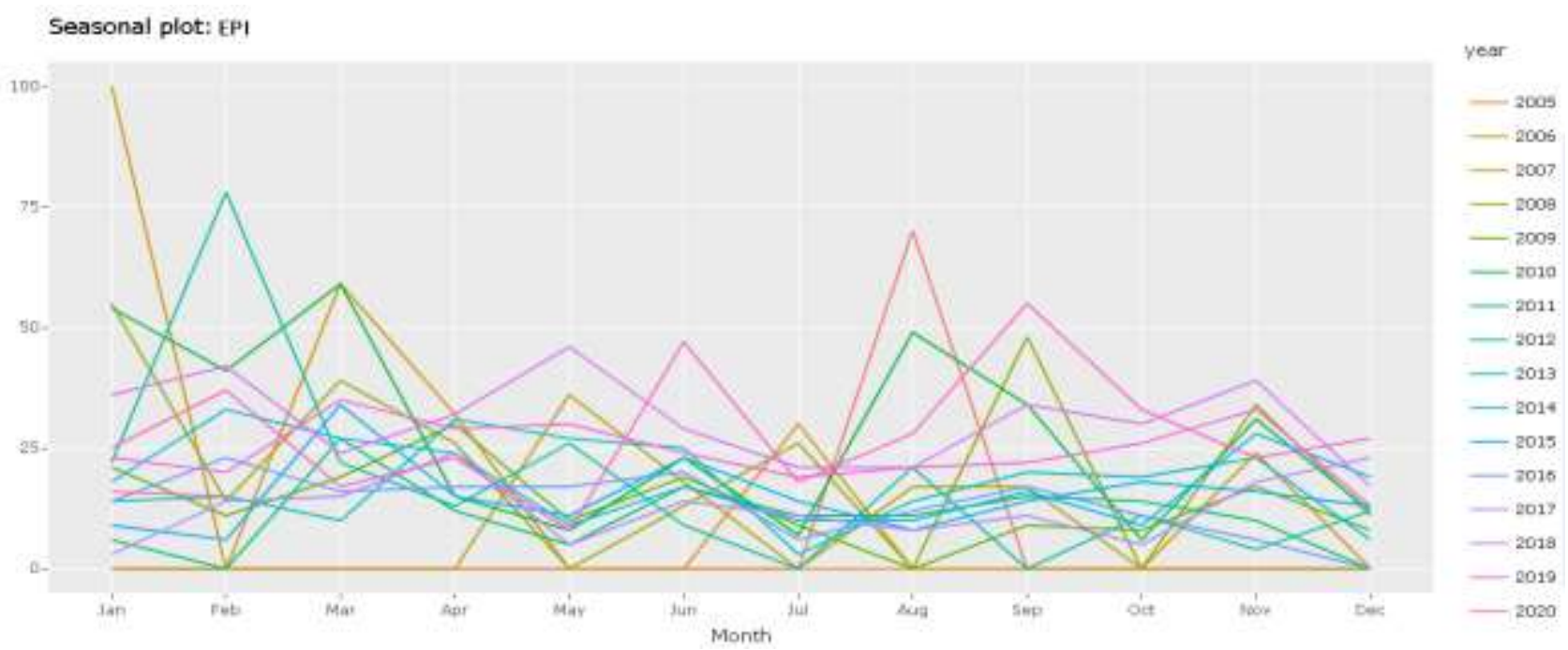

Fig. 7. The seasonality of global requests on the Environmental Performance Index (EPI), $\%$ of the maximum historical value (Jan-2004 - Feb-2021)

\footnotetext{
${ }^{9}$ Object-oriented data type in R.

${ }^{10}$ It converts the data to a Java-driven seasonal trends' plot (made in R programming language for this research).
} 
It can be seen that the pattern in Fig. 6 cannot be explained by the simple seasonal fluctuations shown in Fig. 7. The seventh chart does not show any significant seasonal fluctuations, except for the frequent decline in interest at the end of a year.

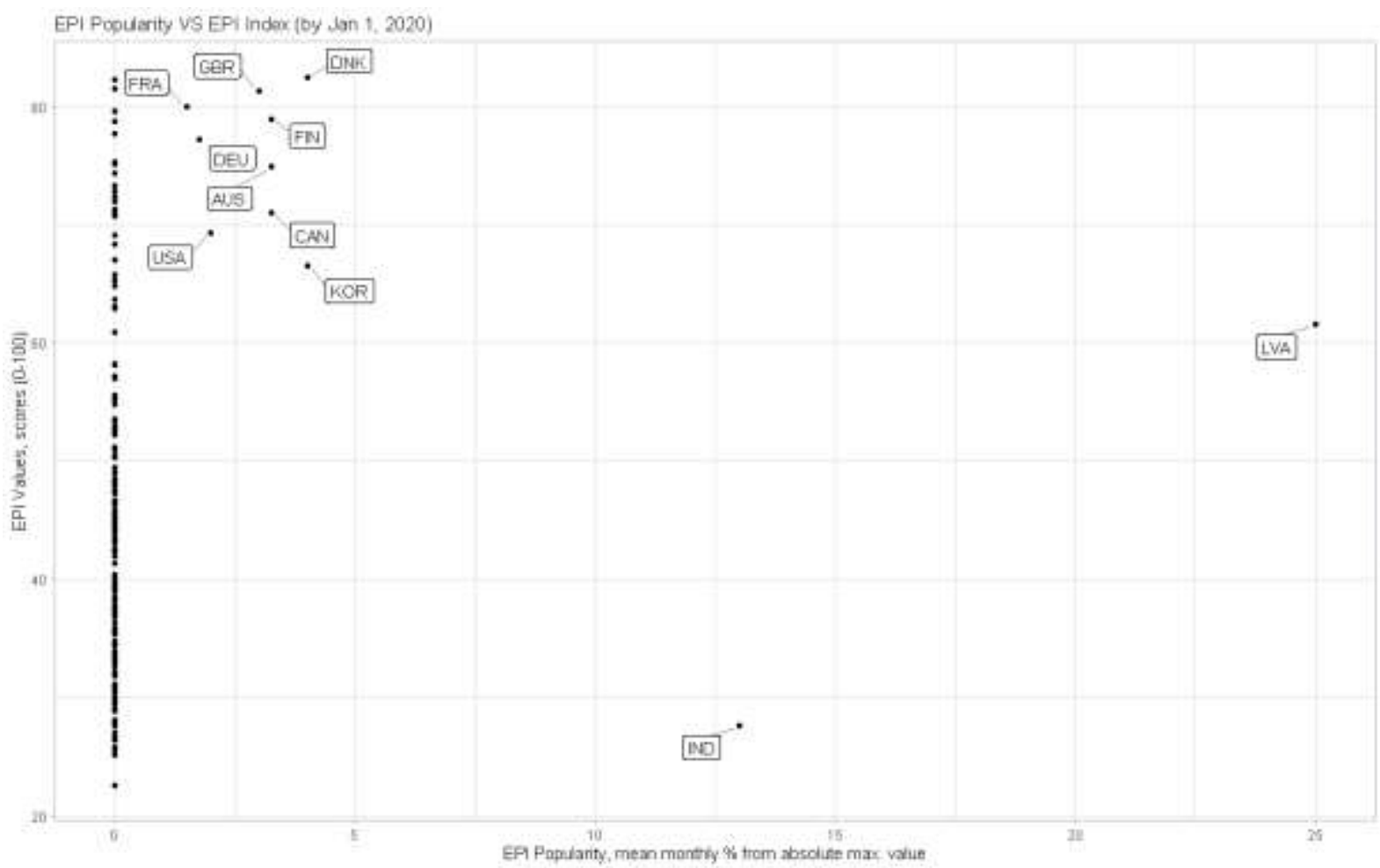

Fig. 8. The popularity of EPI at the internet (mean monthly \% from absolute maximum value, 0-100\%) VS EPI Values (scores: 0 - 100), by January 1, 2020

Fig. 8 is created for this research in programming language R. The ISO-3 country codes are represented for all countries with the non-zero popularity of the EPI-index (extra-small values [below 0.0001] are ignored). The main popularity of the index falls on 11 countries. Nine of these countries are among the countries with the highest index value. The most popular in science Advanced Environmental Index (EPI) is too narrowly specific. EPI is only popular in a limited number of countries. This index was created to assess the sustainable use of natural resources and the effectiveness of environmental protection systems. However, its actual use is limited among narrow specialists in 11 countries.

This study proposes a new index. This is a global index of the popularity of environmental queries (GIPEQ). It shows the cumulative global popularity of environmental queries for the world as a whole and for each country separately (from the search engines like Google). The algorithm for creating this index is written in the R programming language for this study.

Data privacy is ensured by using a percentage of the maximum. This approach allows working with guaranteed confidential data. 


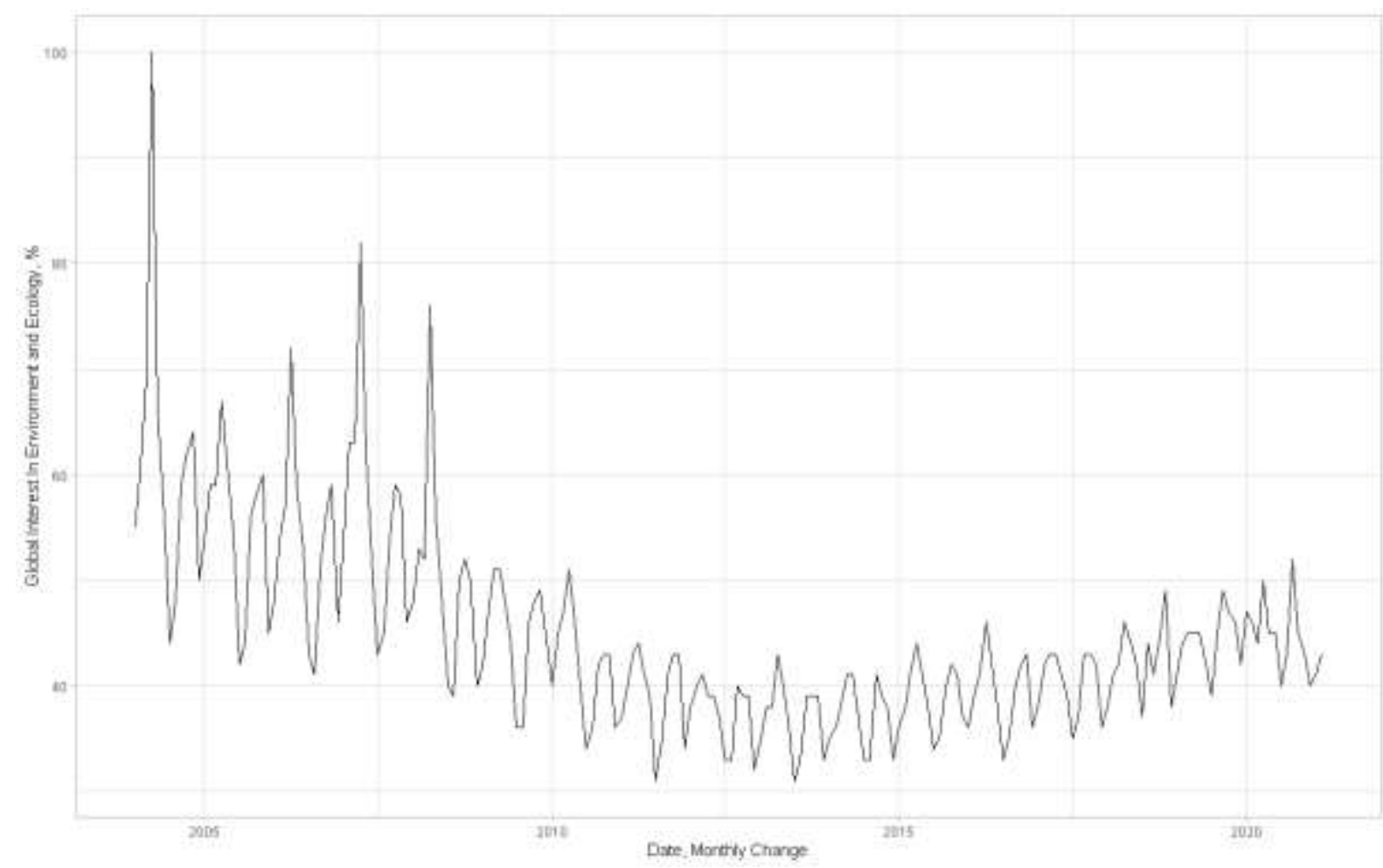

Fig. 9. The estimation of the GIPEQ index through the global popularity of ecology and environment (in \% of the absolute maximum value) in search engines (mainly, Google; all requests categorized as "Ecology and Environment"), Jan-1-2004 - Feb-1-2021

The popularity of ecology and environmental protection queries is parabolic (convex). The peak of popularity is 2004, after which the popularity of ecology and environmental protection requests declined until 2014. The average popularity of queries has been growing after 2014 .

At the same time, it is important to take into account the seasonal patterns of popularity change for ecology and environmental protection requests. Popularity peaks in April each year. The second pike occurs in the fall of each year. The least popularity of ecology and environmental protection falls in the summer period, as well as in December and January. This pattern is described in more detail in Figure 10, which is compiled in the R language for this study.

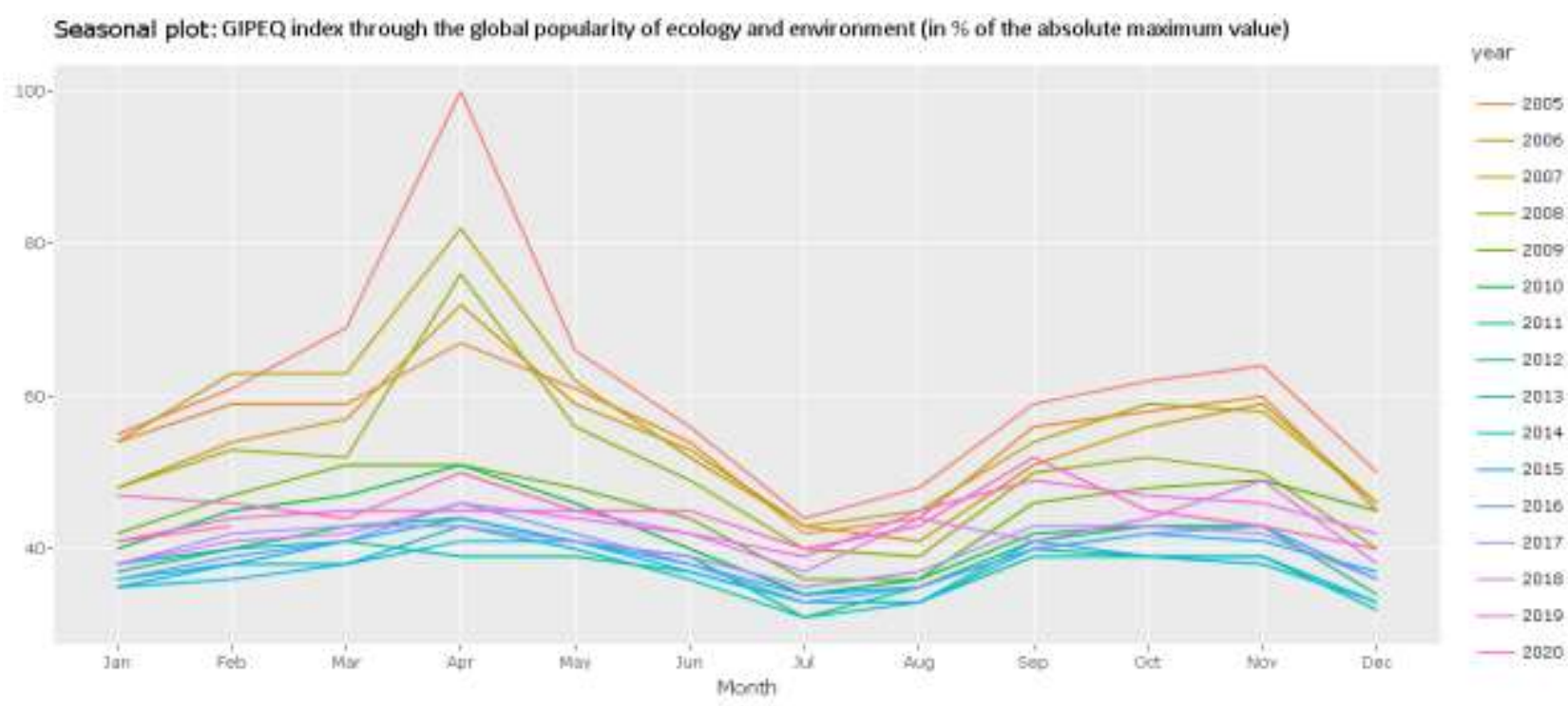

Fig. 10. The seasonal pattern in the estimation of the GIPEQ index through the global popularity of ecology and environment (in \% of the absolute maximum value) in search engines (mainly, Google; all requests categorized as "Ecology and Environment"), Jan-1-2004 - Feb-1-2021 
The most popular language is English for finding information on ecology and environmental protection. The top 19 most popular environmental queries are made in the English language. These discoveries allow for the correct prioritization of the language in which information on sustainable resource use and environmental protection systems should be disseminated.

Table 1

\section{The suggested global EPI deflator from CIPEQ 1 annual changes}

\begin{tabular}{|c|c|c|}
\hline Year & GIPEQ 1 & $\begin{array}{c}\text { Global EPI Deflator } \\
(2019 \text { is 100\%) }\end{array}$ \\
\hline 2016 & 74,53 & 87,56 \\
\hline 2017 & 75,26 & 88,42 \\
\hline 2018 & 79,09 & 92,92 \\
\hline 2019 & 85,11 & 100 \\
\hline 2020 & 82,98 & 97,49 \\
\hline 2021 & 84 & 98,69 \\
\hline
\end{tabular}

Table 1 is developed for this study. It is currently the only methodology for transforming EPI data for time series analysis. Increasing public pressure for environmental projects encourages policymakers to improve their ecological performance (which improves the EPI scores).

\section{Conclusion}

The first works devoted to the analysis based on the macroeconomic data dates back to 1941 (S. Kuznets, 1941; S. S. Kuznets, 1941; Smith, 1942); these researches paid insignificant to none attention to the environmental performance indicators when estimating the economic successes of different countries.

One of the first works devoted to the ecological standards in economy suggested that the national economy should generate same or even greater amounts of income in the infinite number of future periods (Hicks, 1959). This method suggests the time series analysis which is impossible to be performed on a complex level up to until now; even the most complex environmental performance index (EPI that combines most impact-researches on this issue) is not suitable for the time-series analysis (Conrad \& Cassar, 2019; Mbiriri et al., 2017; Wendling et al., 2020; Yale University, 2021).

The research question: what indicator could estimate the popularity of ecology and environmental programs in the world? The global index of the popularity of environmental queries (GIPEQ) is designed to answer the research question.

The additional research question is how to estimate it? A special algorithm to reprocess the search queries from the most popular search engines (mostly Google) is designed to reply to this question. This algorithm estimates the average change from the maximum popularity of the queries related to the ecology and environment.

The main hypothesis is that this indicator could potentially be used for estimating the time series of the complex EPI by estimating the EPI deflator. Deflating the EPI from a specific period is the only known way to control for the time-series analysis for the EPI indicator.

\section{References}

1. Arrow, K., Dasgupta, P., Goulder, L., Daily, G., Ehrlich, P., Heal, G., ... Walker, B. (2004). Are we consuming too much? Journal of Economic Perspectives. https://doi.org/10.1257/0895330042162377

2. Atkinson, G., Dubourg, R., Hamilton, K., Munasinghe, M., Pearce, D., \& Young, C. (1997). Measuring sustainable development: macroeconomics and the environment. In Measuring sustainable development: macroeconomics and the environment. https://doi.org/10.5860/choice.35-3982

3. Batabyal, A. A., \& Dasgupta, P. (2002). Human Well-Being and the Natural Environment. Journal of Range Management. https://doi.org/10.2307/4003234

4. Brekke, K. A., Howarth, R. B., \& Nyborg, K. (2003). Status-seeking and material affluence: Evaluating the Hirsch hypothesis. Ecological Economics. https://doi.org/10.1016/S0921-8009(02)00262-8

5. Chetty, R., Stepner, M., Abraham, S., Lin, S., Scuderi, B., Turner, N., ... Cutler, D. (2016). The association between income and life expectancy in the United States, 2001-2014. JAMA - Journal of the American Medical Association. 
https://doi.org/10.1001/jama.2016.4226

6. Conrad, E., \& Cassar, L. F. (2019). The Environmental Performance Index. In Routledge Handbook of Sustainability Indicators. https://doi.org/10.4324/9781315561103-19

7. Daniel, L. M., \& Ehrlich, P. R. (1990). For the common good: Redirecting the economy toward community, the environment, and a sustainable future. Ecological Economics. https://doi.org/10.1016/0921-8009(90)90021-1

8. Dasgupta, P., \& Mäler, K. G. (2000). Net national product, wealth, and social well-being. Environment and Development Economics. https://doi.org/10.1017/S1355770X00000061

9. Fonte, M. (2013). Food consumption as social practice: Solidarity Purchasing Groups in Rome, Italy. Journal of Rural Studies. https://doi.org/10.1016/j.jrurstud.2013.07.003

10. Gabe, T. (2017). The pursuit of economic development: growing good jobs in US cities and states. https://doi.org/10.1007/978-3-319-52476-4

11. Gerlagh, R., Dellink, R., Hofkes, M., \& Verbruggen, H. (2002). A measure of sustainable national income for the Netherlands. Ecological Economics. https://doi.org/10.1016/S0921-8009(02)00021-6

12. Gibbs, D. (2005). Local economic development and the environment. In Local Economic Development and the Environment. https://doi.org/10.4324/9780203994429

13. Gilland, B., Daly, H. E., \& Cobb, J. B. (1990). For the Common Good: Redirecting the Economy Toward Community, the Environment, and a Sustainable Future. Population and Development Review. https://doi.org/10.2307/1972837

14. Hayek, F. A., \& Bartley, III, W. W. (2013). The Fatal Conceit. In The Fatal Conceit. https://doi.org/10.7208/chicago/9780226321158.001.0001

15. Hicks, J. R. (1959). A "value and capital" growth model. Review of Economic Studies. https://doi.org/10.2307/2295744

16. Hofkes, M. W., Gerlagh, R., \& Linderhof, V. (2011). Sustainable National Income: A Trend Analysis for the Netherlands for 1990-2000. SSRN Electronic Journal. https://doi.org/10.2139/ssrn.1009284

17. Kuznets, S. (1941). The Structure of the American Economy, 1919-1929. By Wassily W. Leontief. Cambridge: Harvard University Press, 1941. Pp. xi, 181. \$2.50. The Journal of Economic History. https://doi.org/10.1017/s0022050700053158

18. Kuznets, S. S. (1941). HANSEN, ALVIN H. Fiscal Policy and Busi ness Cycles. Pp. 462. New York: W. W. Norton \& Co., 1941. \$3.75. The ANNALS of the American Academy of Political and Social Science. https://doi.org/10.1177/000271624121700181

19. López, R., \& Mitra, S. (2000). Corruption, pollution, and the Kuznets environment curve. Journal of Environmental Economics and Management. https://doi.org/10.1006/jeem.1999.1107

20. Mbiriri, R. P., Ozili, P. K., Mbiriri, R. P., Branch, I., Relations, E., Division, I., ... Ganiyu, R. (2017). Can Zimbabwe Use Its Informal Economy As a Means for Sustainable Development. SSRN Electronic Journal.

21. Shemetev, A. (2020). $R$ Package alexandershemetev. Retrieved from https://github.com/Alexandershemetev/alexandershemetev

22. Smith, J. G. (1942). KUZNETS, SIMON. National Income and Its Composition, 1919-1938. Vol. I, pp. xxx, 387; Vol. II, 388-929. New York: National Bureau of Economic Research, 1941. \$5.00. The ANNALS of the American Academy of Political and Social Science. https://doi.org/10.1177/000271624222100161

23. Weitzman, M. L., \& Löfgren, K. G. (1997). On the welfare significance of Green accounting as taught by parable. Journal of Environmental Economics and Management. https://doi.org/10.1006/jeem.1996.0966

24. Wendling, Z. A., Emerson, J. W., de Sherbinin, A., \& Esty, D. C. (2020). Environmental Performance Index. Retrieved from epi.yale.edu

25. Yale University. (2021). Statistical Databases of the population and GDP. Retrieved from https://epi.yale.edu/ 